\title{
Teknologi Informasi Percepatan Pelayanan Publik Pembuatan Paspor pada Kantor Imigrasi
}

\author{
Nurmalasyiah $^{\mathrm{a}} *$ \\ ${ }^{\text {a }}$ STIA Tabalong, Kalimantan Selatan, Indonesia
}

\section{INFORMASI ARTIKEL}

\section{Article history:}

Dikirim tanggal: 31 Agustus 2016

Revisi pertama tanggal: 02 Oktober 2016

Diterima tanggal: 14 November 2016

Tersedia online tanggal: 28 November 2016

Keywords: information technology, public services

\begin{abstract}
The article aims to analyze the acceleration of information technology in public service to the community in term of making a passport which organized by the immigration office. Role of Information Technology is necessary in all elements, such as; institutions, agency, organisation and everyone who related with the service sector. Data from various studies indicate that the use of information technology is very influence to accelerate quality in the public service, especially in the process of passport services. Mastery of Information Technology at the present time has become imperative, more specifically, to the institution including facilitate the administrative work in the public service sector.
\end{abstract}

\section{INTISARI}

Tujuan penulisan artikel ini adalah untuk menganalisis teknologi informasi dalam percepatan pelayanan kepada masyarakat atau publik dalam pembuatan paspor yang diselenggarakan oleh Kantor Imigrasi. Peranan teknologi informasi sangatlah diperlukan pada semua elemen, seperti lembaga, instansi, dinas dan organiasasi bahkan juga diperlukan oleh semua yang terkait dengan sektor pelayanan. Data dari hasil berbagai penelitian menunjukkan bahwa penggunaan teknologi informasi sangat berpengaruh dalam percepatan kualitas pelayanan publik, khususnya dalam proses pelayanan pembuatan paspor. Penguasaan teknologi informasi pada masa sekarang ini sudah menjadi keharusan, lebih khusus lagi bagi institusi atau lembaga, termasuk juga memperlancar pekerjaan administrasi di sektor pelayanan publik.

\section{Pendahuluan}

Semakin canggihnya teknologi informasi pada saat ini seiring dengan berjalannya waktu, oleh karena itu untuk menjamin hak warga negara dalam mendapatkan pelayanan publik secara cepat melalui sistem teknologi informasi. Pelayanan Publik berdasarkan UndangUndang No. 25 Tahun 2009 adalah kegiatan atau rangkaian kegiatan dalam rangka pemenuhan kebutuhan pelayanan sesuai dengan peraturan Undang-Undang bagi setiap warga negara dan penduduk atas barang, jasa, atau pelayanan administratif yang disediakan oleh penyelenggara pelayanan publik. Maka yang harus dilakukan adalah percepatan Pelayanan publik melalui penggunaan Teknologi Informasi sebagai perwujudan dari pelaksanaan Undang-Undang Nomor 25 Tahun 2009 tersebut. Oleh karenanya penyelenggaraan pelayanan publik saaat ini dan kedepannya dalam

* Corresponding author. Tel.: +62-813-5122-0193; e-mail: nurmala.syiah@gmail.com 
rangka mencapai Word Class Goverment pada Tahun 2025 (Kementrian Kementerian Pendayagunaan Aparatur Negara Dan Reformasi Birokrasi, 2014); bukan menjadi pekerjaan yang biasa-biasa saja, tetapi harus menjadi pekerjaan yang luar biasa dengan melakukan percepatan melalui berbagai terobosan baru. Peningkatan pelayanan publik saat ini dibandingkan dengan harapan masyarakat diilustrasikan antara deret hitung berbanding deret ukur. Kemajuan pelayanan publik yang berjalan seperti deret hitung akan semakin jauh ketinggalan dari harapan masyarakat yang melompat seperti deret ukur. Inovasi pelayanan publik merupakan percepatan membuat lompatan terobosan untuk menjadi solusi peningkatan kualitas pelayanan publik yang lebih mendekatkan dengan harapan masyarakat.

\section{Pembahasan}

Inovasi merupakan perubahan menuju hal-hal yang baru. Menurut Mulgan dan Albury (dalam Muluk, 2008) dikatakan bahwa inovasi yang sukses merupakan kreasi dan implementasi dari proses, produk, layanan, dan metode pelayanan baru yang merupakan hasil pengembangan nyata dalam efisiensi, efektifitas atau kualitas hasil. Inovasi pelayanan publik dikatakan sebagai inisiatif terobosan dari instansi/ lembaga publik dalam upaya meningkatkan kualitas pelayanan publik, dalam hal ini penggunaan sistem teknologi informasi. Inisiatif terobosan tersebut terletak pada kebaharuan (novelty). Prinsif kebaharuan tersebut dibedakan dengan inovasi dalam teknologi yang merupakan keunikan yang khas berbeda dengan yang lain. Kebaharuan boleh merupakan pengembangan dari inovasi pelayanan publik yang telah ada, karena inovasi pelayanan publik terus diperbaharui dan bahkan ditiru dengan cara melakukan replikasi. Dengan bahasa populer replikasi inovasi pelayanan publik dilakukan dengan proses yang mudah, yaitu Amati, Tiru dan Modifikasi atau disingkat ATM. Sistem Teknologi Informasi sangat menunjang dalam proses penyelenggaraan percepatan pelayanan publik. Beberapa waktu lalu Menteri Hukum dan HAM RI, Yasonna H. Laoly menyampaikan bahwa untuk meningkatkan pelayanan publik, Kemenhunkam selalu berupaya memberikan inovasi dalam memenuhi kebutuhan masyarakat untuk kemudahan, kecepatan, keamanan dan kenyamanan (Widyastuti, 2016). Salah satu inovasi yang baru tersebut adalah kemudahan dalam pembuatan paspor. Saat ini, pembuatan dengan cara Early Morning Service atau pelayanan pagi hari yang dibuka mulai pukul 06.00 WIB untuk hari Selasa dan Jum'at, pelayanan pembuatan paspor ini langsung dilakukan petugas dengan cepat. Selain itu, pemohon juga mendapatkan jaminan waktu penyelesaian paspor selama tiga jam terhitung dari pemohon mulai melakukan login dan pengambilan nomor antrian sampai proses administrasi dan verifikasi selesai dilakukan. Setelah paspor selesai pemohon akan menerima sms pemberitahuan bahwa paspor selesai dibuat, pengambilan dan penyerahan paspor dapat langsung diambil di Kantor Imigrasi atau dikirim langsung ke alamat via pos dan bagi pengendara atau drive-thru bisa langsung mengambil paspor secara drive-thru, informasi ini dapat diakses pada http//www.imigrasi.go.id. Paspor adalah merupakan sebuah dokumen resmi yang dikeluarkan oleh pejabat yang memiliki wewenang dari suatu negara yang berisi identitas pemilik paspor yang meliputi foto pemegang, tanda tangan, tempat dan tanggal lahir, informasi kebangsaan dan informasi lainnya untuk melakukan perjalanan antar negara dengan jangka waktu yang ditentukan. Paspor biasanya diperlukan saat kita tiba diperbatasan suatu negara untuk memperlihatkan identitas kita sebagai warga negara asing bagi negara yang kita kunjungi. Paspor akan diberi stempel (cap) atau segel dengan visa yang dilakukan oleh petugas negara setempat. Namun dibeberapa negara tertentu ada perjanjian tertentu dimana warga dari suatu negara tertentu dapat memasuki negara tertentu ada perjanjian tertentu dapat memasuki negara lain dengan dokumen selain paspor. Untuk membuat sebuah paspor kita harus mendatangi kantor imigrasi terdekat karena Kantor Imigrasi tidak selalu ada di kabupaten kota, untuk meminta izin pembuatan paspor tersebut, yang mana dalam pembuatan paspor tersebut sudah ada syarat yang telah ditentukan, namun seiring berkembangnya teknologi, ketersediaan pembuatan paspor dilakukan secara online.

Beberapa langkah yang harus dilakukan sebelum anda mendaftar secara online, tentunya ada berkas yang harus anda persiapkan, yaitu sebagai berikut:

a) Scan e-KTP;

b) Scan Kartu Keluarga;

c) Scan Ijazah/Akta Kelahiran/Surat Nikah; dan

d) File diatas jangan diberikan warna.

Selanjutnya kelengkapan yang sudah disiapkan tadi, anda masukan dalam persyaratan untuk pembuatan paspor online. Langkah selanjutnya, yaitu sebagai berikut:

a) Buka situs www.imigrasi.go.id. Pilihlah layanan sesuai keinginan yang akan anda lakukan yaitu membuat paspor online;

b) Pilihlah untuk formulir pemohon;

c) Pilih paspor biasa;

d) Ikuti semua isian yang disesuaikan dengan e-KTP;

e) Lanjutkan pengisiannya;

f) Upload semua berkas data;

g) Teruskan kelangkah berikutnya;

h) Pilihlah kantor Imigrasi yang terdekat dengan anda tinggal;

i) Setelah itu klik lanjut; 
j) Pilih verifikasi;

k) Cetaklah bukti pemohon untuk proses wawancara, pembayaran dan juga foto;

1) Cetak kartu verifikasi;

m) Kemudian proses pencocokan data saat wawancara dilakukan;

n) Foto diri untuk dipaspor yang disertai dengan pembayaran; dan

o) Paspor bisa diambil setelah 3 hingga 7 hari.

Demikianlah tahapan-tahapan dalam proses pembuatan paspor online, mudah saja tanpa harus menggunakan waktu yang lama dan panjang, cepat selesai dan tidak berbelit-belit dalam pembuatannya. Apabila hal tersebut diatas terkendala karena keterbatasan waktu yang anda miliki, maka anda/ masyarakat dapat menggunakan jasa lembaga yang telah ditunjuk oleh kantor Imigrasi secara resmi dan berbadan hukum dalam membantu dan mengurus segalanya yang berkaitan dalam pembuatan paspor. Masyarakat hanya perlu menyerahkan data-data yang diperlukan dalam pembuatan paspor tersebut.

\section{Kesimpulan}

Teknologi informasi dalam percepatan pelayanan publik pembuatan paspor pada kantor imigrasi sangat mempunyai peranan penting untuk memenuhi kualitas pelayanan pada kantor imigrasi. Terutama pembuatan paspor dengan sistem online. Dengan adanya kemudahan pembuatan paspor ini, pelayanan yang diberikan kepada masyarakat semakin baik sehingga masyarakat menjadi puas akan pelayanan publik yang diberikan. Kemenhunkam selalau berupaya memberikan pelayanan yang terbaik bagi masyarakat, sehingga apa yang dibutuhkan oleh masyarakat bisa terpenuhi. Kemenhunkam akan selalu membuat terobosanterobosan baru yang inovatif untuk meningkatkan kualitas pelayanan publik seiring dengan perkembangn teknologi.

Oleh karena itu sumber daya manusialah yang menjadi kunci terlaksananya teknologi informasi dalam percepatan pembuatan paspor, karena teknologi informasi ini harus dijalankan oleh orang yang memiliki kemampuan dan kapabilitas dalam bidang teknologi informasi. Dengan demikian agar hasil yang dicapai dapat maksimal, peran pejabat pemerintah dan pihak yang berwenang untuk meningkatkan sumber daya manusianya tentulah sangat diharapkan terutama dibidang teknologi informasi yang sangat dibutuhkan saat ini.

\section{Daftar Pustaka}

Muluk, Khairul. (2008). Knowledge Management Kunci Sukses Inovasi Pemerintahan Daerah. Jatim: Bayumedia Publising.
Peraturan Presiden Republik Indonesia Nomor 81 Tahun 2010 tentang Grand Design Reformasi Birokrasi 2010 - 2025, Kementerian Pendayagunaan Aparatur Negara Dan Reformasi Birokrasi.

Undang-undang Republik Indonesia Nomor 25 Tahun 2009 tentang Pelayanan Publik.

Widyastuti, Lista. (2016). Pengaruh Teknologi Dalam Meningkatkan Kualitas Pelayanan Publik Pada Kementerian Hukum dan HAM RI. Dapat diakses pada

http://www.hukumpedia.com/hanunku/pengaruhteknologi-dalam-meningkatkan-kualitaspelayanan-publik-pada-kementerian-hukum-danham-ri/ [Diakses 10 Agustus 2016]. 